\title{
PENGARUH CAFÉ ATMOSPHERE, FOOD QUALITY DAN SERVICE QUALITY TERHADAP CUSTOMER SATISFACTION DAN REPURCHASE INTENTION
}

\author{
Gunarso Wiwoho \\ Email: gunarsowiwoho@yahoo.com
}

\begin{abstract}
Abstrak
Penelitian ini bertujuan untuk menguji dan mengalanisis pengaruh dari café atmosphere, food quality, service quality terhadap customer satisfaction dan repurchase intention pada konsumen Beranda Eatery Kebumen. Tujuan penelitian ini adalah menganalisis dan menjelaskan pengaruh antara variabel independen, variabel intervening dan variabel dependen. Populasi penelitian ini yaitu konsumen Beranda Eatery Kebumen.Sampel dalam penelitian ini sebanyak 100 orang.Teknik pengambilan sampel yang digunakan adalah accidental sampling. Metode pengumpulan data dengan kuesioner. Sikap responden diukur dengan skala likert 4 tingkatan dan data yang diperoleh diolah dengan analisis SPSS (Statistical Product and Service Solution) for windows versi 22. Analisis data menggunakan analisis deskriptif, dan analisis statistik (analisis jalur).Hasil penelitian menunjukkan bahwa terdapat pengaruh signifikan antara variabel café atmosphere terhadap customer satisfaction, food quality berpengaruh signifikan terhadap customer satisfaction, selanjutnya service quality berpengaruh signifikan terhadap customer satisfaction, cafe atmosphere berpengaruh signifikan terhadap repurchase intention, food quality tidak berpengaruh signifikan terhadap repurchase intention, service quality berpengaruh signifikan terhadap repurchase intention, serta customer satisfaction berpengaruh signifikan terhadap repurchase intention.
\end{abstract}

Kata Kunci : café atmosphere, food quality, service quality, customer satisfaction, repurchase intention.

\begin{abstract}
This study aims to examine and analyze the effect of café atmosphere, food quality, service quality on customer satisfaction and repurchase intention on consumers in the Beranda Eatery Kebumen. The purpose of this study is to analyze and explain the influence between independent variables, intervening variables and dependent variables. The population of this research is the consumer of the Beranda Eatery Kebumen. The sample in this study is 100 people. The sampling technique used was accidental sampling. The method of data collection with questionnaire. Respondents' attitudes are measured with a 4-level Likert scale and the data obtained are processed by SPSS (Statistical Product and Service Solution) analysis for Windows version 22. Data analysis uses descriptive analysis, and statistical analysis (path analysis).The results showed that there was a significant influence between café atmosphere variables on customer satisfaction, food quality had a significant effect on customer satisfaction, then service quality had a significant effect on customer satisfaction, cafe atmosphere had a significant effect on repurchase intention, food quality had no significant effect on repurchase intention, service quality has a significant effect on repurchase intention, and customer satisfaction has a significant effect on repurchase intention.
\end{abstract}

Key Words: café atmosphere, food quality, service quality, customer satisfaction, repurchase intention. 


\section{PENDAHULUAN}

Bisnis kuliner terus berkembang dan bertambah setiap tahunnya di Indonesia, baik yang berasal dari dalam negeri maupun restoran franchise (waralaba) dari luar negeri. Ketatnya persaingan yang terjadi saat ini menyebabkan usaha pada bidang yang sejenis berlomba lomba untuk menjadi yang terbaik, agar dapat mengambil hati para konsumenya dan memenangkan persaingan. Usaha kuliner saat ini mendapatkan banyak perhatian dari masyarakat, sehingga tidak heran jika banyak pelaku bisnis yang mencoba membuka bisnis kuliner untuk mendapatkan keuntungan besar yang nantinya akan berpengaruh pada peningkatan penjualannya. Bisnis kuliner merupakan salah satu dari sekian banyak bisnis jasa yang berkembang dengan pesat walaupun pada masa krisis, karena pada dasarnya makanan merupakan salah satu kebutuhan pokok manusia yang harus dipenuhi.

Selain menguntungkan dari bisnis kuliner tersebut, faktor utama yang mendorong para pebisnis menggeluti bisnis kuliner yaitu terjadinya perubahan pola hidup pada masyarakat dimana sudah mulai terbiasa untuk makan diluar rumah, karena selain efisien hal tersebut juga dijadikan sebagai sarana refreshing baik bersama keluarga ataupun bersama kerabat. Melihat pertumbuhan jumlah restoran atau café menunjukkan bahwa tingkat persaingan dalam bisnis kuliner semakin ketat, untuk mengatasi persaingan yang semakin ketat tersebut para pelaku usaha dituntut untuk menciptakan strategi pemasaran yang berorientasi pada konsumen. Menurut McDonald \& Keegan (dalam Sugianto dan Sugiono, 2013: 1) pemasaran yang berorientasi pada konsumen merupakan pemasaran yang menekankan pada pemuasan kebutuhan dan keinginan konsumen. Kepuasan pelanggan merupakan suatu perasaan atau penilaian emosional dari pelanggan atas penggunaan suatu produk barang atau jasa dimana harapan dan kebutuhan mereka terpenuhi (Sugianto dan Sugiono, 2013: 4).

Konsumen yang merasa puas dengan suatu produk ataupun jasa akan membeli lagi produk tersebut dikemudian hari, dengan melihat hal tersebut berarti kepuasan pelanggan merupakan kunci yang dapat membuat konsumen tersebut melakukan repurchase intention. Repurchase intention merupakan keinginan yang timbul dari dalam diri konsumen untuk membeli produk ataupun jasa yang sebelumnya pernah dibelinya karena adanya rasa suka atau ada kesesuaian antara harapan konsumen dengan kinerja produk atau jasa.

Berdasarkan hasil wawancara yang dilakukan penelitian pada konsumen Beranda Eatery Kebumen, mereka semua menyatakan puas. Mereka merasa puas dengan fasilitas yang ada di Beranda Eatery. Responden tersebut mengatakan bahwa mereka tidak hanya melakukan pembelian di Beranda Eatery sebanyak satu kali, ada beberapa alasan atau faktor yang menyebabkan konsumen Beranda Eatery melakukan pembelian, mereka memberikan alasan yang berbeda-beda dalam niat pembelian ulang (repurchase intention) pada Beranda Eatery Kebumen.

Tabel 1

Faktor yang Mempengaruhi Niat Beli Ulang Pada Konsumen Beranda Eatery Kebumen

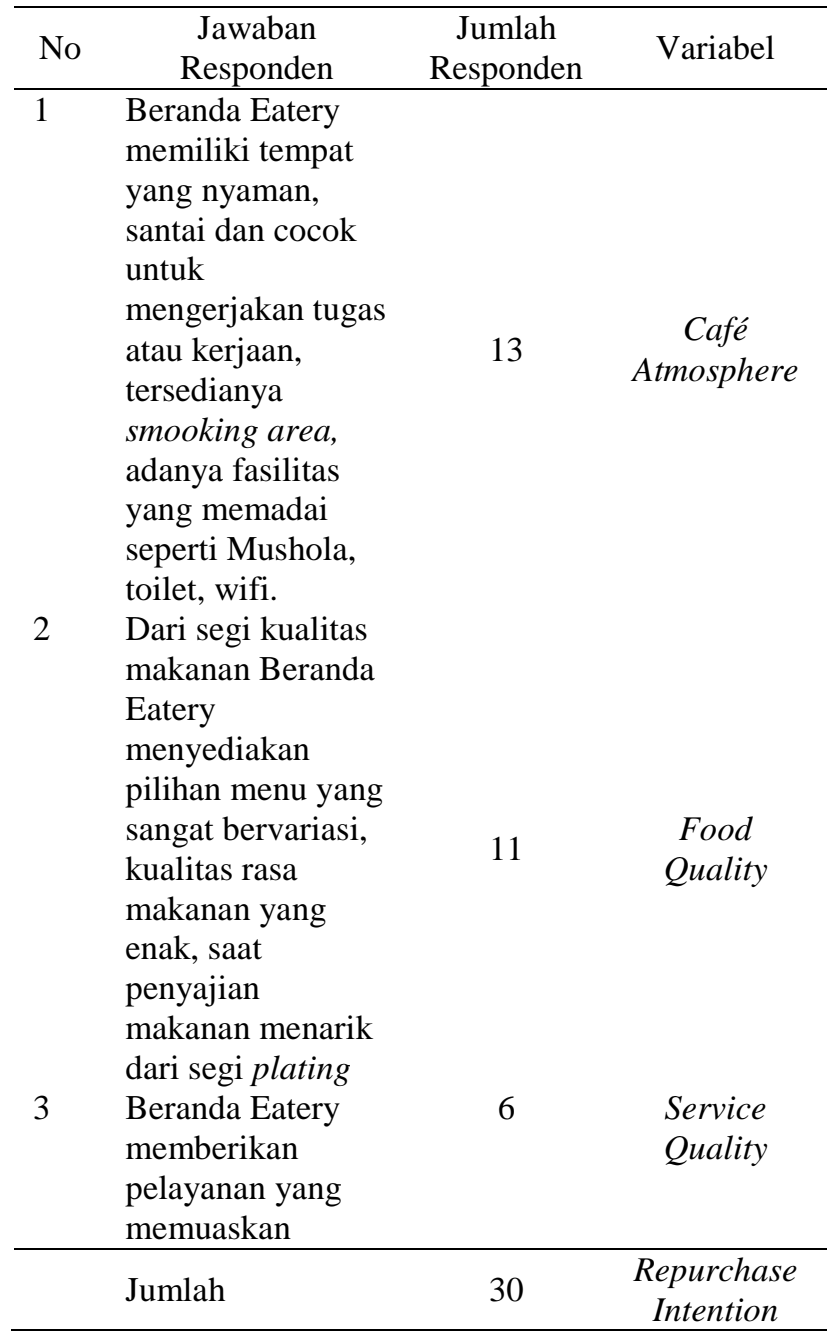

Berdasarkan tabel I-1, dapat diketahui bahwa yang menjadi faktor yang mempengaruhi niat pembelian ulang konsumen Beranda Eatery Kebumen yaitu café atmosphere (suasana kafe), food quality (kualitas makanan) dan service quality (kualitas pelayanan). Ketiga faktor tersebut diyakini menjadi faktor yang dominan dalam menentukan niat beli ulang (repurchase intention) pada café Beranda Eatery Kebumen.

Kotler (2009: 138) menyatakan bahwa kepuasan adalah perasaan senang atau kecewa seseorang yang timbul karena membandingkan kinerja yang dipersepsikan produk (atau hasil) terhadap ekspektasi mereka. Kepuasan yang dirasakan oleh konsumen Beranda Eatery akan membuat bertahannya konsumen tersebut untuk tetap menggunakan jasa yang ditawarkan oleh Beranda Eatery. Jika konsumen tidak puas maka ia akan mencari café lain yang sejenis. Perusahaan harus memuaskan para 
konsumennya supaya konsumen melakukan pembelian ulang dikemudian hari.

Menurut Saintz (2018: 77) repurchase atau pembelian kembali adalah bagaimana konsumen pernah melakukan pembelian pertama yang ternyata ekspektasi dan harapannya terpenuhi, sehingga menciptakan kepuasan terhadap café tersebut, adanya rasa kepuasan inilah yang menjadi dasar adanya pembelian kembali. Konsumen Beranda Eatery yang melakukan pembelian kembali ia merasakan bahwa ekspektasi dan harapannya terpenuhi sehingga mereka merasakan adanya kepuasan akhirnya memutuskan untuk melakukan repurchase intention. Berdasarkan latar belakang diatas, penulis bermaksud untuk melakukan penelitian dengan mengambil judul "Pengaruh Cafe Atmosphere, Food Quality Dan Service Quality Terhadap Customer Satisfaction Dan Repurchase Intention Pada Konsumen Beranda Eatery Kebumen".

\section{Tujuan Penelitian}

1. Untuk mengetahui pengaruh café atmosphere terhadap customer satisfaction di Beranda Eatery Kebumen.

2. Untuk mengetahui pengaruh food quality terhadap customer satisfaction di Beranda Eatery Kebumen.

3. Untuk mengetahui pengaruh service quality terhadap customer satisfaction di Beranda Eatery Kebumen.

4. Untuk mengetahui pengaruh café atmosphere terhadap repurchase intention di Beranda Eatery Kebumen.

5. Untuk mengetahui pengaruh food quality terhadap repurchase intention di Beranda Eatery Kebumen.

6. Untuk mengetahui pengaruh service quality terhadap repurchase intention di Beranda Eatery Kebumen.

7. Untuk mengetahui pengaruh customer satisfaction terhadap repurchase intention di Beranda Eatery Kebumen.

\section{KAJIAN TEORI}

\section{Repurchase Intention}

Menurut Thamrin dan Francis (dalam Septiawati, 2018:21) niat beli ulang merupakan niat pembelian yang didasarkan atas pengalaman pembelian yang telah dilakukan dimasa lalu.Niat beli ulang yang tinggi mencerminkan tingkat kepuasan yang tinggi dari konsumen ketika memutuskan untuk mengadopsi suatu produk.Keputusan untuk mengadopsi atau menolak suatu produk timbul setelah konsumen mencoba suatu produk dan kemudian timbul rasa suka atau tidak suka terhadap produk tersebut. Tingginya niat beli ulang akan membawa dampak yang positif terhadap keberhasilan produk di pasar.

Menurut Ferdinand (dalam Hadani, 2008:132) niat beli ulang dapat diidentifikasi melalui empat indikator yaitu: (1) Niat transaksional, (2) Niat referensial, (3) Niat preferensial dan (4) Niat eksploratif.

\section{Customer Satisfaction}

Menurut Cendriono dan Titin (2018) kepuasan konsumen merupakan hasil dari perbandingan antara harapan dan kenyataan yang diterima oleh pelanggan dalam mengkonsumsi barang dan jasa.Menurut Kotler dan Armstrong (2012) kepuasan pelanggan adalah hasil yang dirasakan oleh pembeli yang mengalami kinerja sebuah usaha yang sesuai dengan harapannya.

Menurut Tjiptono (2007) membatasi customer satisfaction dengan tiga dimensi yaitu: (1) Overall satisfaction (kepuasan general atau keseluruhan), (2) Confirmation or expectation (konfirmasi harapan) dan (3) Comparison to ideal (perbandingan situasi).

\section{Café Atmosphere}

Menurut Albert Kurniawan Purnomo (2017: 135) café atmosphere adalah sebuah lingkungan yang ditata menarik dengan dukungan cahaya, warna, musik, wewangian dan sebagainya untuk menimbulkan respon emosi tertentu sebagai pendorong untuk melakukan pembelian.

Indikator café atmosphere diambil dari indikator store atmospere, menurut Berman dan Evans (dalam Listiono dan Sugiono, 2015:2) membagi indikator store atmosphere kedalam empat elemen yaitu: (1) Eksterior, (2) General interior (3) Store layout dan (4) Interior point of purchase display.

\section{Food Quality}

Menurut Potter dan Hotchkiss (dalam Salsabila, 2018:142) food quality adalah karakteristik kualitas dari suatu makanan yang dapat diterima oleh konsumen. Menurut Essinger dan Wylie (dalam Sugianto dan Sugiono, 2013:3) membagi produk khususnya masakan atau makanan dalam enam dimensi yaitu sebagai berikut: (1) Kualitas dalam hal rasa, (2) Kuantitas atau porsi, (3) Variasi menu dan variasi jenis masakan yang ditawarkan, (4) Cita rasa yang khas, (5) Higienitas atau kebersihan dan (6) Inovasi.

\section{Service Quality}

Service quality adalah ukuran seberapa bagus tingkat layanan yang diberikan mampu sesuai dengan ekspektasi pelanggan (Tjiptono, 2005). Kualitas pelayanan dapat diukur dengan menggunakan lima dimensi, yang biasa disebut dengan model SERQUAL. Kelima dimensi tersebut menurut Parasuraman, Zeithmal dan Berry (dalam Adhityo Prabowo, 2015) ada lima dimensi penentu kualitas jasa yaitu: (1) Reliability (keandalan), (2) Responsiveness (ketanggapan), (3) Assurance (jaminan), (4) Emphaty (empati) dan (5) Tangible (bukti fisik). 


\section{MODEL EMPIRIS}

Gambar 1

Model Empiris
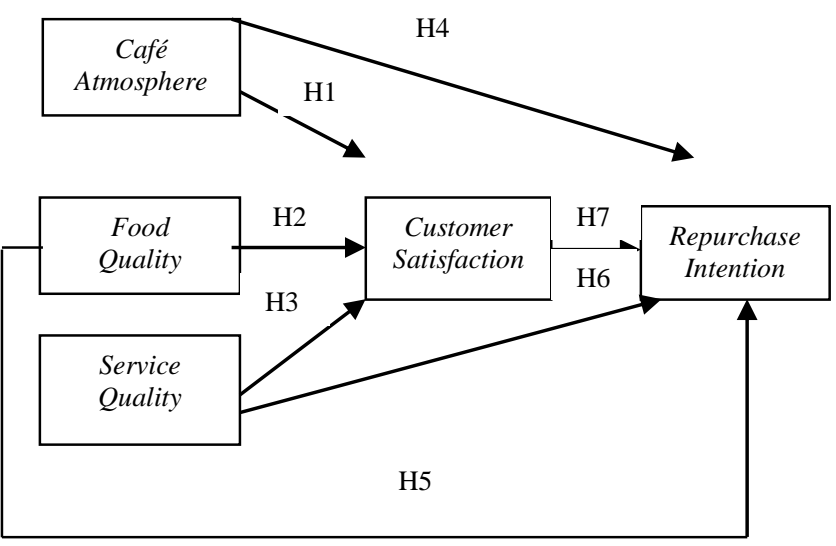

H1 : Terdapat pengaruh café atmosphere terhadap customer satisfaction pada konsumen Beranda Eatery Kebumen

$\mathrm{H} 2$ : Terdapat pengaruh food quality terhadap customer satisfaction pada konsumen Beranda Eatery Kebumen

H3 :Terdapat pengaruh service quality terhadap customer satisfaction pada konsumen Beranda Eatery Kebumen

$\mathrm{H} 4$ :Terdapat pengaruh café atmosphere terhadap repurchase intention pada konsumen Beranda Eatery Kebumen

H5 : Terdapat pengaruh food quality terhadap repurchase intention pada konsumen Beranda Eatery Kebumen

H6 :Terdapat pengaruh service quality terhadap repurchase intention pada konsumen Beranda Eatery Kebumen

H7 : Terdapat pengaruh customer satisfaction terhadap repurchase intention pada konsumen Beranda Eatery Kebumen

\section{METODE}

Penelitian ini dilakukan pada konsumen yang pernah melakukan pembelian di Beranda Eatery Kebumen. Pengambilan sampel menggunakan teknik non probability sampling yaitu accidental sampling dengan jumlah responden sebanyak 100 orang. Pengumpulan data menggunakan kuesioner dengan skala likert, dengan masing-masing kuesioner mengenai repurchase intention 4 item pertanyaan, kuesioner customer satisfaction 4 item pertanyaan, kuesioner café atmosphere 7 item pertanyaan, kuesioner food quality 6 item pertanyaan, kuesioner service quality 5 item pertanyaan.

Teknik pengumpulan data yang dilakukan dengan cara : (1) menyebar kuesioner kepada konsumen Beranda Eatery; (2) wawancara ; (3) studi pustaka. Instrumen dalam penelitian ini dilakukan dengan menggunakan kuesioner yang ditunjukkan untuk memperoleh jawaban dari responden. Alat bantu pengolahan data menggunakan SPSS for windows versi 22 . Teknik analisis data dilakukan dengan dua cara yaitu analisis deskriptif dan analisis statistika. Analisis data secara statistika meliputi: (1) uji validitas dan uji reliabilitas; (2) uji asumsi klasik; (3) uji hipotesis; (4) analisis korelasi; (5) analisis jalur.

\section{HASIL DAN PEMBAHASAN \\ Uji Validitas}

Menentukan $r_{\text {tabel }}$ (Ghozali, 2009) dengan rumus

$$
\text { df }=n-2
$$

Keterangan:

$\mathrm{df}=$ degree offreedom

$\mathrm{n}$ = sampel

Dengan level of significance $95 \%$ maka dasar analisisnya (Ghozali, 2009):

a. Apabila $r_{\text {hitung }}>r_{\text {tabel }}$ dengan tingkat signifikansi $<$ 0,05 berarti item tersebut valid.

b. Apabila $r_{\text {hitung }}<r_{\text {tabel }}$ dengan tingkat signifikansi $>$ 0,05 berarti item tersebut tidak valid.

\section{Tabel 1}

Hasil Uji Validitas Café Atmosphere

\begin{tabular}{|c|c|c|c|c|}
\hline Butir & $\mathrm{r}_{\text {hitung }}$ & $\mathrm{r}_{\text {tabel }}$ & Signifikansi & Ket \\
\hline $\mathrm{X} 1.1$ & 0.625 & 0.198 & 0.000 & Valid \\
\hline $\mathrm{X} 1.2$ & 0.688 & 0.198 & 0.000 & Valid \\
\hline $\mathrm{X} 1.3$ & 0.674 & 0.198 & 0.000 & Valid \\
\hline $\mathrm{X} 1.4$ & 0.671 & 0.198 & 0.000 & Valid \\
\hline $\mathrm{X} 1.5$ & 0.684 & 0.198 & 0.000 & Valid \\
\hline $\mathrm{X} 1.6$ & 0.587 & 0.198 & 0.000 & Valid \\
\hline
\end{tabular}

Tabel 2

Hasil Uji Validitas Food Quality

\begin{tabular}{|c|c|c|c|c|}
\hline Butir & $\mathrm{R}_{\text {hitung }}$ & $\mathrm{R}_{\text {tabel }}$ & Signifikansi & Ket \\
\hline X2.1 & 0.651 & 0.198 & 0.000 & Valid \\
\hline X2.2 & 0.695 & 0.198 & 0.000 & Valid \\
\hline X2.3 & 0.719 & 0.198 & 0.000 & Valid \\
\hline X2.4 & 0.714 & 0.198 & 0.000 & Valid \\
\hline X2.5 & 0.722 & 0.198 & 0.000 & Valid \\
\hline X2.6 & 0.739 & 0.198 & 0.000 & Valid \\
\hline
\end{tabular}

Tabel 3

Hasil Uji Validitas Service Quality

\begin{tabular}{|c|c|c|c|c|}
\hline Butir & $\mathrm{r}_{\text {hitung }}$ & $\mathrm{r}_{\text {tabel }}$ & Signifikansi & Ket \\
\hline X3.1 & 0.511 & 0.198 & 0.000 & Valid \\
\hline X3.2 & 0.721 & 0.198 & 0.000 & Valid \\
\hline X3.3 & 0.834 & 0.198 & 0.000 & Valid \\
\hline X3.4 & 0.755 & 0.198 & 0.000 & Valid \\
\hline X3.5 & 0.675 & 0.198 & 0.000 & Valid \\
\hline
\end{tabular}

Tabel 4

Hasil Uji Validitas Customer Satisfaction

\begin{tabular}{|c|c|c|c|c|}
\hline Butir & $\mathrm{r}_{\text {hitung }}$ & $\mathrm{r}_{\text {tabel }}$ & Signifikansi & Ket \\
\hline Y1.1 & 0.716 & 0.198 & 0.000 & Valid \\
\hline Y1.2 & 0.805 & 0.198 & 0.000 & Valid \\
\hline Y1.3 & 0.744 & 0.198 & 0.000 & Valid \\
\hline Y1.4 & 0.783 & 0.198 & 0.000 & Valid \\
\hline
\end{tabular}


Tabel 5

Hasil Uji Validitas Repurchase Intention

\begin{tabular}{|c|c|c|c|c|}
\hline Butir & $\mathrm{r}_{\text {hitung }}$ & $\mathrm{r}_{\text {tabel }}$ & Signifikansi & Ket \\
\hline Y2.1 & 0.706 & 0.198 & 0.000 & Valid \\
\hline Y2.2 & 0.778 & 0.198 & 0.000 & Valid \\
\hline Y2.3 & 0.817 & 0.198 & 0.000 & Valid \\
\hline Y2.4 & 0.704 & 0.198 & 0.000 & Valid \\
\hline
\end{tabular}

Berdasarkan tabel diatas menunjukkan semua instrumen Café Atmosphere, Food Quality, Service Quality, Customer Satisfaction dan Repurchase Intention dinyatakan valid karena $r_{\text {hitung }}>r_{\text {tabel }}(0.198)$, dengan tingkat signifikansi sebesar $0.000<0.05$ sehingga semua item yang dipakai dinyatakan valid atau sah.

\section{Uji Reliabilitas}

Uji reliability butir dilakukan dengan ketentuan jika Cronbach's Alpha > $\mathrm{r}_{\text {kritis }}$ (0.60) sehingga dapat disimpulkan bahwa semua instrumen dalam penelitian dinyatakan reliable dan sebaliknya.

Tabel 6

Hasil Uji Reliabilitas

\begin{tabular}{|c|c|c|c|}
\hline Variabel & $\mathrm{R}_{\text {kritis }}$ & $\begin{array}{c}\text { Cronbach's } \\
\text { Alpha }\end{array}$ & Ket \\
\hline $\mathrm{X} 1$ & 0.60 & 0.773 & Reliabel \\
\hline $\mathrm{X} 2$ & 0.60 & 0.796 & Reliabel \\
\hline $\mathrm{X} 3$ & 0.60 & 0.740 & Reliabel \\
\hline $\mathrm{Y} 1$ & 0.60 & 0.759 & Reliabel \\
\hline $\mathrm{Y} 2$ & 0.60 & 0.740 & Reliabel \\
\hline
\end{tabular}

Berdasarkan tabel diatas, hasil analisis dapat dijelaskan bahwa seluruh variabel yang dipakai dalam penelitian ini dinyatakan reliable karena Cronbach's Alpha $>\mathrm{r}_{\text {kritis }}(0.60)$.

Uji Asumsi Klasik

Uji Multikolonieritas

Tabel 7

Hasil Uji Multikolonieritas

Substruktural 1

\begin{tabular}{|l|c|c|}
\hline \multicolumn{1}{|c|}{ Model } & \multicolumn{2}{c|}{ Collinearity Statistics } \\
\hline & Tolerance & VIF \\
\hline Café Atmosphere & 0.260 & 3.853 \\
\hline Food Quality & 0.234 & 4.271 \\
\hline Service Quality & 0.522 & 1.915 \\
\hline
\end{tabular}

Tabel 8

Hasil Uji Multikolonieritas

Substruktural 2

\begin{tabular}{|l|c|c|}
\hline \multicolumn{1}{|c|}{ Model } & \multicolumn{2}{c|}{ Collinearity Statistics } \\
\hline & Tolerance & VIF \\
\hline Café Atmosphere & 0.248 & 4.036 \\
\hline Food Quality & 0.215 & 4.645 \\
\hline Service Quality & 0.490 & 2.039 \\
\hline Customer Satisfaction & 0.382 & 2.619 \\
\hline
\end{tabular}

Berdasarkan tabel diatas, dapat diketahui bahwa nilai tolerance diatas 0.10 dan VIF diatas 10 , sehingga model regresi tidak terjadi multikolonieritas.

Uji Heteroskedastisitas

Gambar 2. Uji Heteroskedastisitas Substruktural 1

Scatterplot

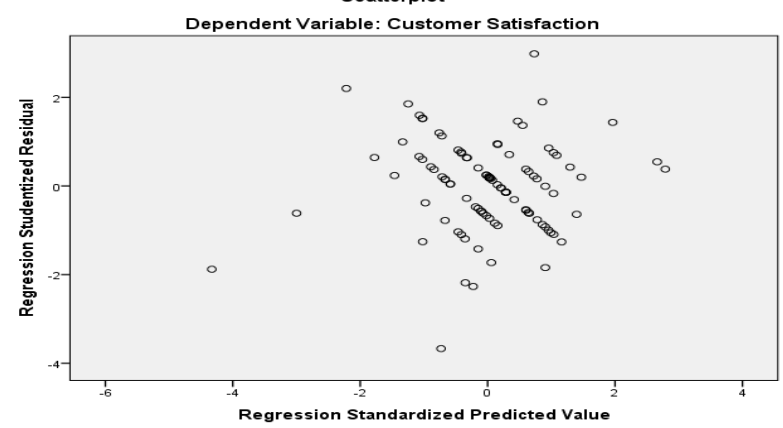

Gambar 3. Uji Heteroskedastisitas

Substruktural 2

Scatterplot

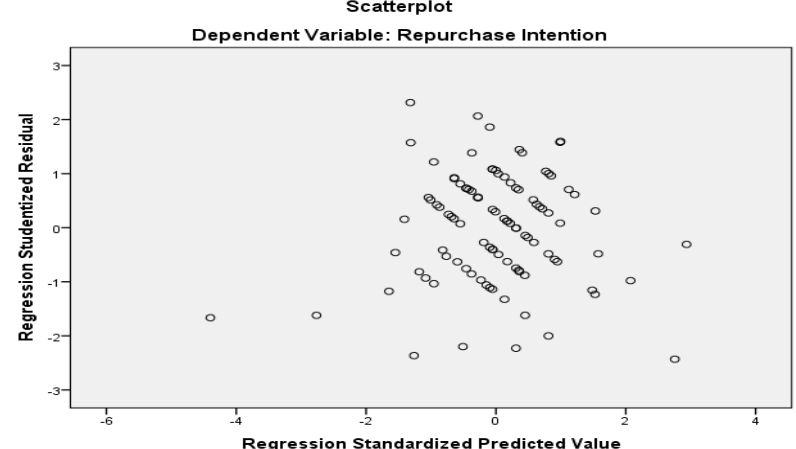

Berdasarkan gambar diatas menunjukkan bahwa tidak ada pola tertentu seperti titik-titik yang membentuk suatu pola tertentu yang jelas, sehingga dapat disimpulkan model regresi pada penelitian ini tidak terjadi heteroskedastisitas.

\section{Uji Normalitas}

Gambar 4. Uji Normalitas Substruktural 1

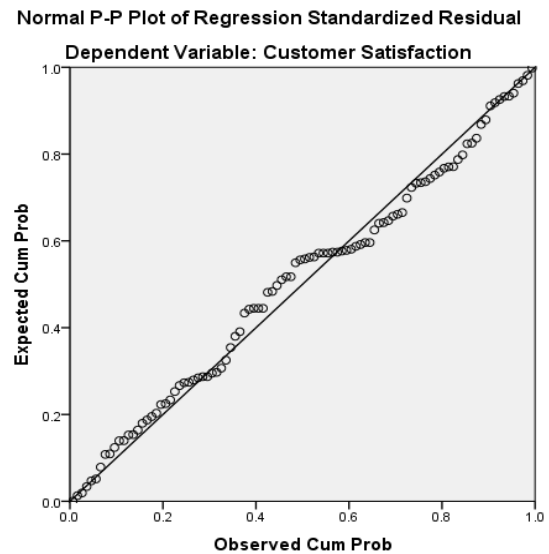

Gambar 5. Uji Normalitas Substruktural 2 


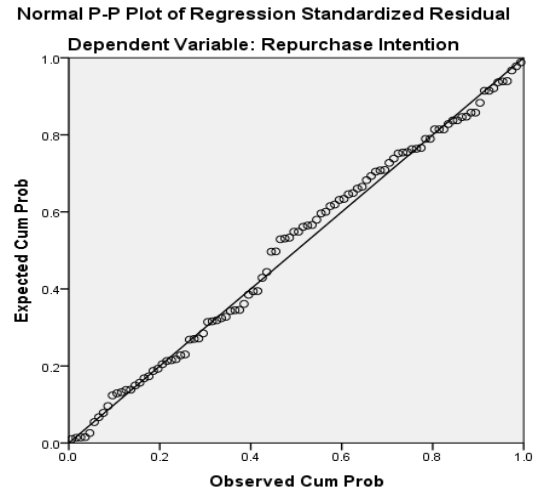

Berdasarkan gambar diatas (Normal P-P Plot of Regression Standardized Residual) diketahui bahwa data menyebar disekitar garis diagonal. Maka model regresi tersebut memenuhi asumsi normalitas.

\section{Uji Hipotesis}

\section{Uji Hipotesis Parsial (Uji t) \\ Tabel 9 \\ Hasil Uji Parsial (Uji T) Substruktural 1 Coefficients $^{\mathrm{a}}$}

\begin{tabular}{|l|l|l|l|c|c|}
\hline Model & \multicolumn{2}{|l|}{$\begin{array}{l}\text { Unstandardize } \\
\text { d Coefficients }\end{array}$} & $\begin{array}{l}\text { Standa } \\
\text { rdized } \\
\text { Coeffic } \\
\text { ients }\end{array}$ & $\mathrm{t}$ & Sig. \\
\hline & B & $\begin{array}{l}\text { Std. } \\
\text { Error }\end{array}$ & Beta & & \\
\hline constant & 1.273 & .951 & & 1.338 & .184 \\
\hline X1 & .182 & .085 & .265 & 2.140 & .035 \\
\hline X2 & .245 & .084 & .378 & 2.900 & .005 \\
\hline X3 & .176 & .071 & .217 & 2.491 & .014 \\
\hline
\end{tabular}

Dependent Variable: Customer Satisfaction

Tabel 10

Hasil Uji Parsial (Uji t) Substruktural 2 Coefficients $^{\mathrm{a}}$

\begin{tabular}{|l|l|l|l|l|l|}
\hline Model & \multicolumn{2}{|l|}{$\begin{array}{l}\text { Unstandardized } \\
\text { Coefficients }\end{array}$} & $\begin{array}{l}\text { Standar } \\
\text { dized } \\
\text { Coeffic } \\
\text { ients }\end{array}$ & $\mathrm{t}$ & Sig. \\
\hline & B & $\begin{array}{l}\text { Std.E } \\
\text { rror }\end{array}$ & Beta & & \\
\hline constant & 1.140 & 1.191 & & .957 & .341 \\
\hline X1 & .236 & .108 & .323 & 2.181 & .032 \\
\hline X2 & -.058 & .109 & -.084 & -.527 & .599 \\
\hline X3 & .233 & .091 & .271 & 2.571 & .012 \\
\hline Y1 & .288 & .127 & .272 & 2.277 & .025 \\
\hline
\end{tabular}

Dependent Variable: Repurchase Intention

Berdasarkan tabel 9 dan 10 , maka dapat dilihat hasil uji t yang menunjukkan hasil pengaruh tiap variabel dalam penelitian ini adalah sebagai berikut:
Tabel 11

Hasil Pengaruh Variabel

\begin{tabular}{|c|c|c|c|c|}
\hline Hipotesis & Variabel & $t_{\text {hitung }}$ & $t_{\text {tabel }}$ & Konseptual \\
\hline $\mathrm{H} 1$ & $\mathrm{X} 1 \rightarrow \mathrm{Y} 1$ & 2.140 & 1.985 & Signifikan \\
\hline $\mathrm{H} 2$ & $\mathrm{X} 2 \rightarrow \mathrm{Y} 1$ & 2.900 & 1.985 & Signifikan \\
\hline $\mathrm{H} 3$ & $\mathrm{X} 3 \rightarrow \mathrm{Y} 1$ & 2.491 & 1.985 & Signifikan \\
\hline $\mathrm{H} 4$ & $\mathrm{X} 1 \rightarrow \mathrm{Y} 2$ & 2.181 & 1.985 & Signifikan \\
\hline $\mathrm{H} 5$ & $\mathrm{X} 2 \rightarrow \mathrm{Y} 2$ & -0.527 & 1.985 & $\begin{array}{c}\text { Tidak } \\
\text { signifikan }\end{array}$ \\
\hline $\mathrm{H} 6$ & $\mathrm{X} 3 \rightarrow \mathrm{Y} 2$ & 2.571 & 1.985 & Signifikan \\
\hline $\mathrm{H} 7$ & $\mathrm{Y} 1 \rightarrow \mathrm{Y} 2$ & 2.277 & 1.985 & Signifikan \\
\hline
\end{tabular}

\section{Koefisien Determinasi}

Tabel 12

Hasil uji koefisien determinasi Substruktural 1 Model summary ${ }^{b}$

\begin{tabular}{|l|l|l|l|l|}
\hline Model & $\mathrm{R}$ & $\begin{array}{l}\mathrm{R} \\
\text { Square }\end{array}$ & $\begin{array}{l}\text { Adjusted R } \\
\text { Square }\end{array}$ & $\begin{array}{l}\text { Std. Error } \\
\text { of the } \\
\text { Estimate }\end{array}$ \\
\hline 1 & $.786^{\mathrm{a}}$ & .618 & .606 & 1.10008 \\
\hline
\end{tabular}

a. Predictors: (Constant), Service Quality, Café Atmosphere, Food Quality

b. Dependent Variable: Customer Satisfaction

Berdasarkan tabel diatas hasil pengujian ini menunjukkan bahwa nilai Adjusted $R^{2}$ substruktural 1 sebesar 0.606 artinya sebesar $60.6 \%$ variabel customer satisfaction dapat dijelaskan oleh variabel café atmosphere, food quality dan service quality, sedangkan sebesar 39,4\% (100\% - 60.6\%) dapat dijelaskan oleh variabel lain yang tidak ada dalam model penelitian ini.

Tabel 13

Hasil uji koefisien determinasi Substruktural 2 Model summary ${ }^{\mathrm{b}}$

\begin{tabular}{|l|l|l|l|l|}
\hline Model & $\mathrm{R}$ & $\begin{array}{l}\mathrm{R} \\
\text { square }\end{array}$ & $\begin{array}{l}\text { Adjusted } \mathrm{r} \\
\text { square }\end{array}$ & $\begin{array}{l}\text { Std. error } \\
\text { of the } \\
\text { estimate }\end{array}$ \\
\hline 1 & $.695^{\mathrm{a}}$ & .482 & .461 & 1.36462 \\
\hline
\end{tabular}

a. Predictors : (Constant), Customer Satisfaction, Service Quality, Café Atmosphere, Food Quality

b. Dependent Variable: Repurchase Intention

Berdasarkan tabel diatas hasil pengujian ini menunjukkan bahwa nilai Adjusted $R^{2}$ substruktural 2 sebesar 0.461 artinya sebesar $46.1 \%$ variabel repurchase intention dapat dijelaskan oleh variabel café atmosphere, food quality, service quality dan customer satisfaction sedangkan sebesar $53.9 \%(100 \%$ - 46.1\%) dapat dijelaskan oleh variabel lain yang tidak ada dalam model penelitian ini. 


\section{Analisis Korelasi}

Tabel 14

Hasil Analisis Korelasi

Correlations

\begin{tabular}{|c|c|c|c|c|}
\hline & & $\begin{array}{l}\text { Café } \\
\text { Atmosphere }\end{array}$ & $\begin{array}{l}\text { Food } \\
\text { Quality }\end{array}$ & $\begin{array}{l}\text { Service } \\
\text { Quality }\end{array}$ \\
\hline \multirow{3}{*}{$\begin{array}{l}\text { Café } \\
\text { Atmo } \\
\text { spher } \\
e\end{array}$} & $\begin{array}{l}\text { Pearson } \\
\text { Correlation }\end{array}$ & 1 & $.857^{* *}$ & $.640^{* *}$ \\
\hline & Sig & & .000 & .000 \\
\hline & $\mathrm{N}$ & 100 & 100 & 100 \\
\hline \multirow{3}{*}{$\begin{array}{l}\text { Food } \\
\text { Quali } \\
\text { ty }\end{array}$} & $\begin{array}{l}\text { Pearson } \\
\text { Correlation }\end{array}$ & $.857^{* *}$ & 1 & $.683^{* *}$ \\
\hline & Sig & .000 & & .000 \\
\hline & $\mathrm{N}$ & 100 & 100 & 100 \\
\hline \multirow{3}{*}{$\begin{array}{l}\text { Servi } \\
\text { ce } \\
\text { Quali } \\
\text { ty }\end{array}$} & $\begin{array}{l}\text { Pearson } \\
\text { Correlation }\end{array}$ & $.640^{* *}$ & $.683^{* *}$ & 1 \\
\hline & Sig & .000 & .000 & \\
\hline & $\mathrm{N}$ & 100 & 100 & 100 \\
\hline
\end{tabular}

Berdasarkan tabel diatas dapat disimpulkan bahwa hubungan café atmosphere dengan food quality memiliki nilai sebesar 0.857 sehingga dapat dikatakan memiliki korelasi sangat kuat, café atmosphere dengan service quality memiliki nilai sebesar 0.640 sehingga dapat dikatakan memiliki korelasi kuat dan food quality dengan service quality memiliki nilai sebesar 0.683 sehingga dapat dikatakan memiliki korelasi kuat.

\section{Analisis Jalur}

Analisis jalur merupakan suatu metode penelitian yang utamanya digunakan untuk menguji kekuatan dari hubungan langsung dan tidak langsung di antara berbagai variabel.

\section{Koefisien Jalur}

Koefisien jalur menunjukkan kuatnya pengaruh variabel independen terhadap dependen. Koefisien jalur dapat dihitung dengan persamaan structural yang terdiri dari dua persamaan, dimana $\mathrm{X} 1, \mathrm{X} 2, \mathrm{X} 3$ adalah variabel independen, Y1 dan Y2 adalah variabel dependen, yang dirumuskan sebagai berikut:

$€_{1}=\sqrt{1-R^{2}}=\sqrt{1-0,618}=0,618$

$\mathrm{Y}_{1}=0,265 \mathrm{X} 1+0,378 \mathrm{X} 2+0,217 \mathrm{X} 3+0,618$

Keterangan:

a. Koefisien regresi variabel café atmosphere $(\mathrm{P} 1)=$ 0,265

Koefisien regresi untuk X1 sebesar 0,265 artinya setiap penambahan 1 satuan pada café atmosphere(X1), maka akan menambah customer satisfaction sebesar 0,265.

b. Koefisien regresi variabel food quality (P2) = 0,378

Koefisien regresi untuk X2 sebesar 0,378 artinya setiap penambahan 1 satuan pada variabel food quality (X2), maka akan menambah customer satisfaction sebesar 0,378 . c. Koefisien regresi variabel service quality $(\mathrm{P} 3)=$ 0,217

Koefisien regresi untuk X3 sebesar 0,217 artinya setiap penambahan 1 satuan pada variabel service quality (X3), maka akan menambah customer satisfaction sebesar 0,217.

d. Nilai Residu $\left(€_{1}\right)=0,618$

Nilai residu yang sebesar 0,618 menunjukkan customer satisfaction yang tidak dapat dijelaskan oleh variabel café atmosphere (X1), food quality (X2) dan service quality (X3) diabaikan atau sama dengan 0 (nol).

$€_{2}=\sqrt{1-R^{2}}=\sqrt{1-0,482}=0,719$

$\mathrm{Y}_{2}=0,323 \mathrm{X} 1-0,084 \mathrm{X} 2+0,271 \mathrm{X} 3+0,272 \mathrm{Y} 1+0,719$

Keterangan:

a. Koefisien regresi variabel café atmosphere $(\mathrm{P} 1)=$ 0,323

Koefisien regresi untuk X1 sebesar 0,323 artinya setiap penambahan 1 satuan pada variabel café atmosphere (X1), maka akan menambah repurchase intention sebesar 0,323 .

b. Koefisien regresi variabel food quality $(\mathrm{P} 2)=$ 0,084

Koefisien regresi untuk X2 sebesar 0,084 penambahan 1 satuan pada variabel food quality (X2), maka akan menambah repurchase intention sebesar 0,084

c. Koefisien regresi variabel service quality $(\mathrm{P} 3)=$ 0,271

Koefisien regresi untuk X3 sebesar 0,271 artinya setiap penambahan 1 satuan pada variabel service quality (X3), maka akan menambah repurchase intention sebesar 0,271.

d. Koefisien regresi variabel customer satisfaction $(\mathrm{P} 4)=0,272$

Koefisien regresi untuk Y1 sebesar 0,272 artinya setiap penambahan 1 satuan pada variabel customer satisfaction (Y1), maka akan menambah repurchase intention sebesar 0,272.

e. Nilai Residu $\left(€_{2}\right)=0,719$

Nilai residu yang sebesar 0,719 menunjukkan repurchase intention yang tidak dapat dijelaskan oleh variabel café atmosphere (X1), food quality (X2), service quality (X3) dan customer satisfaction (Y1) diabaikan atau sama dengan 0 (nol).

\section{Implikasi Manajerial}

Penelitian ini bertujuan untuk mengetahui seberapa besar pengaruh café atmospere, food quality dan service quality terhadap customer satisfaction dan repurchase intention. Implikasi yang disarankan dalam penelitian ini adalah sebagai berikut:

1. Pengaruh Café Atmosphere terhadap Cusomer Satisfaction

Pengujian hipotesis pertama dilakukan untuk mengetahui pengaruh café atmosphere terhadap 
customer satisfaction. Berdasarkan hasil uji $\mathrm{t}$ untuk variabel café atmosphere diperoleh nilai $t_{\text {hitung }}$ lebih besar dari $t_{\text {tabel }}$ yaitu 2,140>1,985 dengan nilai signifikansi sebesar $0,035<0,05$. Hal ini menunjukkan bahwa café atmosphere memiliki pengaruh yang signifikan terhadap customer satisfaction. Hasil tersebut menunjukkan bahwa semakin baik penciptaan café atmosphere yang memadai pada Beranda Eatery maka akan meningkatkan kepuasan konsumen. Selanjutnya penelitian ini sejalan dengan penelitian yang dilakukan oleh Florencia Irena Sari Listiono dan Sugiono Sugiarto (2015) bahwa store atmosphere atau café atmosphere berpengaruh positif dan signifikan terhadap customer satisfaction.

2. Pengaruh Food Quality terhadap Customer Satisfaction

Pengujian hipotesis kedua dilakukan untuk mengetahui pengaruh food quality terhadap customer satisfaction. Berdasarkan hasil uji $\mathrm{t}$ untuk variabel food quality diperoleh nilai $t_{\text {hitung }}$ lebih besar dari $\mathrm{t}_{\text {tabel }}$ yaitu 2,900>1,985 dengan nilai signifikansi sebesar $0,005<0,05$. Hal ini menunjukkan bahwa food quality memiliki pengaruh yang signifikan terhadap customer satisfaction. Hasil tersebut menunjukkan bahwa semakin baik food quality yang terdapat pada Beranda Eatery maka akan meningkatkan kepuasan konsumen. Selanjutnya penelitian ini sejalan dengan penelitian yang dilakukan oleh Jimmy Sugiono dan Sugiono Sugiarto (2013) bahwa food quality berpengaruh positif dan signifikan terhadap customer satisfaction.

3. Pengaruh Service Quality terhadap Customer Satisfaction

Pengujian hipotesis ketiga dilakukan untuk mengetahui pengaruh service quality terhadap customer satisfaction. Berdasarkan hasil uji $\mathrm{t}$ untuk variabel service quality diperoleh nilai $\mathrm{t}_{\text {hitung }}$ lebih besar dari $\mathrm{t}_{\text {tabel }}$ yaitu 2,491>1,985 dengan nilai signifikansi sebesar $0,014<0,05$. Hal ini menunjukkan bahwa service quality memiliki pengaruh yang signifikan terhadap customer satisfaction. Hasil tersebut menunjukkan bahwa semakin baik tingkat service quality yang diberikan pada Beranda Eatery maka akan meningkatkan kepuasan konsumen atau customer satisfaction. Selanjutnya penelitian ini sejalan dengan penelitian yang dilakukan oleh Gatot Wibowo, Marjam Desma Rahadhini dan Sunarso (2017) bahwa service quality berpengaruh positif dan signifikan terhadap customer satisfaction.

4. Pengaruh Café Atmosphere terhadap Repurchase Intention

Pengujian hipotesis keempat dilakukan untuk mengetahui pengaruh café atmosphere terhadap repurchase intention. Berdasarkan hasil uji $\mathrm{t}$ untuk variabel café atmosphere diperoleh nilai $\mathrm{t}_{\text {hitung }}$ lebih besar dari $\mathrm{t}_{\text {tabel }}$ yaitu 2,181>1,985 dengan nilai signifikansi sebesar $0,032<0,05$. Hal ini menunjukkan bahwa café atmosphere memiliki pengaruh yang signifikan terhadap repurchase intention. Hasil tersebut menunjukkan bahwa dengan adanya café atmosphere yang baik dan menarik pada Beranda Eatery maka akan menciptakan kesan positif dibenak konsumen untuk melakukan repurchase intention. Penelitian ini sejalan dengan penelitian yang dilakukan oleh Muhammad Azis Nirwana, Particia Dhiana Paramita dan Heru Sri Wulan (2016) bahwa café atmosphere berpengaruh positif dan signifikan terhadap repurcase intention.

5. Pengaruh Food Quality terhadap Repurchase Intention

Pengujian hipotesis kelima dilakukan untuk mengetahui pengaruh food quality terhadap repurchase intention. Berdasarkan hasil uji $\mathrm{t}$ untuk variabel food quality diperoleh nilai $t_{\text {hitung }}$ lebih kecil dari $t_{\text {tabel }}$ yaitu $-0,527<1,985$ dengan nilai signifikansi sebesar 0,599>0,05. Hal ini menunjukkan bahwa food quality tidak berpengaruh signifikan terhadap repurchase intention. Hasil tersebut menjelaskan bahwa kualitas makanan yang ada di Beranda Eatery tidak mempengaruhi repurchase intention. Hasil penelitian ini berbeda dengan penelitian yang dilakukan oleh Gatot Wibowo, Marjam Desma Rahadini dan Sunarso (2017).

6. Pengaruh Service Quality terhadap Repurchase Inttention

Pengujian hipotesis keenam dilakukan untuk mengetahui pengaruh service quality terhadap repurchase intention. Berdasarkan hasil uji $\mathrm{t}$ untuk variabel service quality diperoleh nilai $\mathrm{t}_{\text {hitung }}$ lebih besar dari $\mathrm{t}_{\text {tabel }}$ yaitu 2,571>1,985 dengan nilai signifikansi sebesar $0,012<0,05$. Hal ini menunjukkan bahwa service quality memiliki pengaruh yang signifikan terhadap repurchase intention. Hasil ini menunjukkan semakin baik service quality yang diberikan maka akan mendorong niat beli ulang (repurchase intention). Penelitian ini sejalan dengan penelitian yang dilakukan oleh Gatot Wibowo, Marjam Desma Rahadini dan Sunarso (2017) bahwa service quality berpengaruh positif dan signifikan terhadap repurchase intention.

7. Pengaruh Customer Satisfaction terhadap Repurchase Intention

Pengujian hipotesis ketujuh dilakukan untuk mengetahui pengaruh customer satisfaction terhadap repurchase intention. Berdasarkan hasil uji $\mathrm{t}$ untuk variabel customer satisfaction diperoleh nilai $t_{\text {hitung }}$ lebih besar dari $t_{\text {tabel }}$ yaitu 2,277>1,985 dengan nilai signifikansi sebesar $0,025<0,05$. Hal ini menunjukkan bahwa customer satisfaction memiliki pengaruh yang signifikan terhadap repurchase intention. Hasil tersebut menunjukkan bahwa semakin tinggi tingkat kepuasan yang dirasakan konsumen akan 
semakin kuat dalam memengaruhi niat konsumen untuk melakukan pembelian ulang. Penelitian ini sejalan dengan penelitian yang dilakukan oleh Gatot Wibowo, Marjam Desma Rahadini dan Sunarso (2017) bahwa customer satisfaction berpengaruh positif dan signifikan terhadap repurchase intention.

\section{PENUTUP}

\section{Simpulan}

1. Hipotesis pertama $\left(\mathrm{H}_{1}\right)$ yang menyatakan bahwa café atmosphere berpengaruh positif dan signifikan terhadap customer satisfaction pada Beranda Eatery Kebumen dapat diterima, karena memiliki nilai $t_{\text {hitung }}$ sebesar $2.140>1.985 \mathrm{t}_{\text {tabel }}$ dan tingkat signifikansi sebesar $0.035<0.05$.

2. Hipotesis kedua $\left(\mathrm{H}_{2}\right)$ yang menyatakan bahwa food quality berpengaruh positif dan signifikan terhadap customer satisfaction pada Beranda Eatery Kebumen dapat diterima, karena memiliki nilai $t_{\text {hitung }}$ sebesar $2.900>1.985 \mathrm{t}_{\text {tabel }}$ dan tingkat signifikansi sebesar $0.005<0.05$.

3. Hipotesis ketiga $\left(\mathrm{H}_{3}\right)$ yang menyatakan bahwa service quality berpengaruh positif dan signifikan terhadap customer satisfaction pada Beranda Eatery Kebumen dapat diterima, karena memiliki nilai $t_{\text {hitung }}$ sebesar $2.491>1.985 \mathrm{t}_{\text {tabel }}$ dan tingkat signifikansi sebesar $0.014<0.05$.

4. Hipotesis keempat $\left(\mathrm{H}_{4}\right)$ yang menyatakan bahwa café atmosphere berpengaruh positif dan signifikan terhadap repurchase intention pada Beranda Eatery Kebumen dapat diterima, karena memiliki nilai $t_{\text {hitung }}$ sebesar $2.181>1.985 t_{\text {tabel }}$ dan tingkat signifikansi sebesar $0.032<0.05$.

5. Hipotesis kelima $\left(\mathrm{H}_{5}\right)$ yang menyatakan bahwa food quality tidak berpengaruh signifikan terhadap repurchase intention pada Beranda Eatery Kebumen dapat diterima, karena memiliki nilai $\mathrm{t}_{\text {hitung }}$ sebesar $-0.527<1.985 \mathrm{t}_{\text {tabel }}$ dan tingkat signifikansi sebesar $0.599>0.05$.

6. Hipotesis keenam $\left(\mathrm{H}_{6}\right)$ yang menyatakan bahwa service quality berpengaruh positif dan signifikan terhadap repurchase intention pada Beranda Eatery Kebumen dapat diterima, karena memiliki nilai $t_{\text {hitung }}$ sebesar $2.571>1.985 \mathrm{t}_{\text {tabel }}$ dan tingkat signifikansi sebesar $0.012<0.05$.

7. Hipotesis ketujuh $\left(\mathrm{H}_{7}\right)$ yang menyatakan bahwa customer satisfaction berpengaruh positif dan signifikan terhadap repurchase intention pada Beranda Eatery Kebumen dapat diterima, karena memiliki nilai $t_{\text {hitung }}$ sebesar $2.277>1.985 t_{\text {tabel }}$ dan tingkat signifikansi sebesar $0.025<0.05$.

\section{Saran}

1. Untuk pihak internal Beranda Eatery harus lebih memperhatikan logo Beranda Eatery agar terlihat oleh konsumen. Selain itu pihak internal Beranda Eatery lebih memperhatikan pencahayaan ruangan yang menurut konsumen dirasa tidak nyaman. sehingga akan meningkatkan nilai positif atau kepuasan dari para konsumen yang berkunjung yang nantinya bisa mempengaruhi repurchase intention.

2. Untuk pihak internal Beranda Eatery agar terus mempertahankan pelayanan kepada konsumen, diharapkan dengan memberikan pelayanan yang baik tersebut konsumen akan merasa puas sehingga akan menimbulkan keinginan atau niatan dari konsumen untuk melakukan pembelian atau berkunjung kembali ke Beranda Eatery Kebumen.

3. Peneliti hanya mengambil variabel café atmosphere, food quality, service quality, customer satisfaction dan repurchase intention.Untuk mendapatkan penelitian yang lebih baik perlu menambahkan variabel lain seperti EWOM di media sosial atau promosi mengingat Beranda Eatery merupakan café premium dan memiliki banyak pesaing mengingat sekarang ini mulai berdiri kafe-kafe baru dengan menawarkan atmosphere yang

\section{DAFTAR PUSTAKA}

Adixio, Riko Firmansyah., \& Laila Saleh. 2013. "Pengaruh Kualitas Pelayanan dan Nilai yang Dirasakan Terhadap Niat Pembelian Ulang Melalui Mediasi Kepuasan Pelanggan Restoran Solaria di Surabaya." Journal of Business and Banking, Vol. 3, No. 2.Surabaya : STIE Perbanas.

Anggraeni, Jenni., dkk. 2016. "Pengaruh Keanekaragaman Produk, Kualitas Pelayanan Dan Store Atmosphere Terhadap Impulse Buying Di Butik Cassanova Semarang." Journal Of Management, Vol. 2, No. 2. Semarang : Universitas Pandanaran.

Aryadhe, Trisdayana., dkk. 2018."Pengaruh Sikap dan Norma Subjektif Terhadap Niat Beli Dan Keputusan Pembelian."E-journal Manajemen Unud, Vol. 7, No. 3.Bali : Universitas Udayana.

Cendriono, Nanang.,\& Titin Eka Ardiana. 2018. "Pengaruh Kualitas Pelayanan Terhadap Pembelian Ulang Dawet Jabung yang Dilihat dari Kepuasan Pelanggan Sebagai Variabel Mediasi." Jurnal Akuntansi dan Pajak, Vol. 18, No. 02.Ponorogo : Universitas Muhammadiyah.

Ghozali, Imam. 2005. Aplikasi Analisis Multivariate Dengan Program SPSS. Cetakan Keempat. Semarang : Badan Penerbit Universitas Diponegoro.

Ghozali, Imam. 2009. Aplikasi Analisis Multivariate Dengan Program IBM SPSS 20. Semarang: Badan Penerbit Universitas Diponegoro.

Hadani, Aditya Lazuardi. 2008. “Analisis Pengaruh Kualitas Layanan Terhadap Minat Beli Ulang (Studi Empiris Pada PT. Sriwijaya Air Distrik 
Semarang)". Jurnal Bisnis Strategi, Vol. 17, No. 2. Semarang.

Listiono, Florencia Irena Sari., \& Sugiono Sugiharto. 2015. "Pengaruh Store Atmosphere Terhadap Loyalitas Konsumen Dengan Kepuasan Konsumen sebagai Variabel Intervening di Libreria Eatery Surabaya." Jurnal Manajemen Pemasaran Petra, Vol. 1, No. 1, 1-9. Surabaya : Universitas Kristen Petra.

Mulyamas.2018. Pengaruh Café Atmosphere Dan Kualitas Pelayanan Terhadap Keputusan Pembelian Gen Y Pada Beranda Eatery. Skripsi Sarjana (Tidak dipublikasikan). Kebumen : Sekolah Tinggi Ilmu Ekonomi Putra Bangsa.

Meldarianda, Resti.,\& Henky Lisan S. 2010. "Pengaruh Store Atmosphere Terhadap Minat BeliKonsumen Pada Resort Café Atmosphere Bandung."Jurnal Bisnis dan Ekonomi (JBE), Vol. 17, No. 2, 97108.Bandung : Universitas Kristen Maranatha.

Ningsih, Palupi Setia. 2016. Analisis Pengaruh Restaurant Atmosphere, Service Quality Terhadap Repurchase Intention Dengan Customer Satisfaction Sebagai Variabel Intervening Di Vittenan Resto Kebumen. Skripsi Sarjana (Tidak dipublikasikan). Kebumen : Sekolah Tinggi Ilmu Ekonomi Putra Bangsa.

Nirwana, Muhammad Azis, dkk. 2016. "Influence Store Atmosphere And Quality Of Service For Customer Satisfaction That Influence Repurchase Intention In Boutique Mounira Semarang." Journal of Management, Vol. 02, No. 02.Semarang : Universitas Pandanaran.

Novitasari, Erik.,\& Amelia. 2016. "Analisis Pengaruh Variabel Restaurant Environmental Cues Dan Non-Enviromental Cues Terhadap Repurchase Intention Melalui Customer Satisfaction Pelanggan Richeese Factory Di Surabaya." Jurnal Gema Aktualita, Vol.5, No.1. Surabaya : Universitas Pelita Harapan.

Prabowo, Adhitya. 2015. Pengaruh Store Atmosphere Dan Kualitas Pelayanan Terhadap Minat Beli Ulang (studi kasus pada Klinik Kopi Yogyakarta). Skripsi Sarjana (Tidak dipublikasikan). Yogyakarta : Fakultas Ekonomi Universitas Sanata Dharma

Prastyaningsih, Ayu Sari., dkk. 2014. "Pengaruh Customer Experience Terhadap Repurchase Intention (Niat Membeli Ulang) (Survei Pada Konsumen KFC di Lingkungan Warga RW 3 Desa Kandangrejo, Kedungpring, Lamongan)." Jurnal Administrasi Bisnis (JAB), Vol. 16, No. 1. Malang : Universitas Brawijaya.

Purnomo, Albert Kurniawan. 2017. "Pengaruh Café Atmosphere Terhadap Keputusan Pembelian Gen Y Pada Old Bens Café". Jurnal Manajemen Maranatha, Vol. 16, No. 2. Bandung : Universitas Nurtanio.
Raihana, Zhafira.,\& Putu Yudi Setiawan. 2018. “Ateseden Kepuasan Pelanggan Dan Dampaknya Pada Niat Pembelian Ulang." E-Jurnal Manajemen Unud, Vol. 7, No. 4. Bali : Universitas Udayana.

S, Fiani Margaretha dan Edwin Japarianto.2012. “Analisis Pengaruh Food Quality Dan Brand Image Terhadap Keputusan Pembelian Roti Kecik Toko Roti Ganep'S Di Kota Solo.’Jurnal Manajemen Pemasaran, Vol.1, No.1. Surabaya : Universitas Kristen Petra.

Saintz, Jocellynne. 2018. "Pengaruh Perceived Service Quality Terhadap Repurchase Dan Customer Satisfaction Sebagai Variabel Intervening Pada Fast Food Restaurant diSurabaya." Jurnal Manajemen Pemasaran, Vol. 12, No. 2, 77-83. Surabaya : Universitas Kristen Petra.

Salsabilah, Titah dan Sunarti. 2018. "Pengaruh Food Quality, Dining Atmosphere danKesesuaian Harga Terhadap Kepuasan Pelanggan Café Ria Djenaka Shining Batu." Jurnal Administrasi Bisnis (JAB), Vol. 54, No. 1. Malang : Universitas Brawijaya.

Septiawati, Ratna. 2018. Pengaruh Kualitas Pelayanan Terhadap Niat Pembelian Ulang Produk Dengan Kepuasan Pelanggan Sebagai Variabel Mediasi. Tesis Magister Manajemen (Tidak dipublikasikan), Bandar Lampung: Program Pascasarjana Universitas Lampung.

Simamora, Bilson. 2004. Panduan Riset Perilaku Konsumen. Jakarta : PT Gramedia Pustaka Utama.

Sugianto, Jimmy dan Sugiono Sugiharto. 2013. “Analisa Pengaruh Service Quality, Food Quality, dan Price Terhadap Kepuasan Pelanggan Restoran Yung Ho Surabaya." Jurnal Manajemen Pemasaran Petra, Vol. 1, No. 2, 1-10. Surabaya : Universitas Kristen Petra.

Sugiyono.2010. Metode Penelitian Kuantitatif Kualitatif Dan R\&DCetakan Ke-11. Bandung: Alfabeta.

Sugiyono. 2018. Metode Penelitian Manajemen. Cetakan Ke-6.Bandung: Alfabeta.

Tjiptono, Fandy. 2005. Pemasaran Jasa. Malang : Bayumedia Publishing.

Tjiptono, Fandy., Ph.D, \& Gregorius Chandra. 2011. Service Quality \& Satisfaction Edisi 3. Yogyakarta : Andi.

Umar, Husein. 2010. Riset Pemasaran dan Perilaku Konsumen.Jakarta : PT Gramedia Pustaka Utama.

Weliani, Steffi. 2015. “Analisa Pengaruh Food Quality, Service Person Customer Orientation Dan Physical Environment Terhadap Repurchase Intention Melalui CustomerSatisfaction." Jurnal Ultima Management, Vol. 7, No. 1. Universitas Multimedia Nusantara.

Wibowo, Gatot., dkk. 2017. “Analisis Pengaruh Kualitas Produk Dan Kualitas Pelayanan Terhadap 
Kepuasan Konsumen Dalam Membentuk Niat Beli Ulang”. Jurnal Ekonomi dan Kewirausahaan, Vol. 17, No. 1.Surakarta : Universitas Slamet Riyadi.

Wibowo, Sarwo Eddy., dkk. 2013. "Pengaruh Persepsi Kualitas Pelayanan Terhadap Niat Pembelian Ulang Pada Toko Buku Gramedia Yogyakarta." Jurnal Ekonomi, Vol. 4, No. 1. Jakarta : Fakultas Ekonomi, Universitas Esa Unggul.

Wulanjani, Harimurti.,\& Derriawan. 2017. "Dampak Utilitarian Value Dan ExperientalMarketing Terhadap Customer Satisfaction Dan Revisit Intention." Jurnal riset manajemen dan bisnis (JRMB), Vol.2, No. 2.Jakarta : Universitas Pancasila.

Yudha, Manik Kartika., \& Sri Suprapti. 2018. "Pengaruh Atmosphere Toko dan Daya Tarik Promosi Penjualan Terhadap Kepuasan Pelanggan dan Niat Beli Ulang (Di Matahari Mall Bali Galeria Kuta)." E-Jurnal Ekonomi Dan Bisnis, Vol. 7, No. 7. Bali : Universitas Udayana. 